\title{
Standards of Honey Quality in Polish Legislation
}

\author{
Katarzyna Szyszko Podgórska* \\ Institute of Environmental Protection, Poland
}

*Corresponding author: Katarzyna Szyszko-Podgórska, Institute of Environmental Protection, National Research Institute, Poland

\begin{tabular}{|c|c|}
\hline ARTICLE INFO & ABSTRACT \\
\hline Received: 蔧 July 15, 2019 & Citation: Katarzyna Szyszko Podgórska. Standards of Honey Quality in Polish Legislation. \\
\hline Published: 蔧 July 23, 2019 & Biomed J Sci \& Tech Res 19(5)-2019. BJSTR. MS.ID.003374. \\
\hline
\end{tabular}

\section{Introduction}

About the huge significance of the pro-healthy honey probably no-one needs to be convinced. Honey has healing properties, soothes cough, accelerates wound healing, relieves the liver, lowers cholesterol levels, inhibits cancer and has a beneficial effect on the liver Basista $\mathrm{K}$ [1]. In addition, honeys have an anti-oxidant, analgesic, anti-inflammatory, antibiotic effect and have a nourishing and moisturizing effect on the skin. These valuable properties of honey result from its chemical composition, which is closely related to the species of plant from which nectar or honeydew is taken Ball D [2]. A distinction is made between two types of nectar honey: one from a single plant and a multi-flower from multiple plants. There are also two varieties of honeydew honey, i.e. leaf honeydew and coniferous honeydew. The honeys vary in colour from almost colourless (acacia, rape, dandelion, clover), yellow (lime, heather) to brown (buckwheat, chestnut) (Marciniak E 2014). The conducted research shows that the quality of some honeys available on the Polish market does not meet the requirements specified in the Polish Standard and binding regulations Hodujko M et al. [3-7].

In accordance with current legislation, the criteria which must be met by honeys marketed in the European Union and in Poland as a product intended for human consumption are defined in : Council Directive 2001/110/EC of 20 December 2001 relating to honey (OJ L 10, 12.1.2002, p. 47), Directive 2014/63/EU of the European Parliament and of the Council of 15 May 2014 amending Council Directive 2001/110/EC relating to honey (OJ L 164, 3.6.2014, p. 1), Regulation of the Minister of Agriculture and Rural Development of 3 October 2003, Codex Alimentarius [8]. Codex Standard for Honey. Codex Stan 12-1981 5 and Polish Standard PN-88/A-77626 "Miód pszczeli". In accordance with $§ 15$. 1. of the Regulation of the Minister for Agriculture and Rural Development of 3 October 2003 on detailed requirements concerning the commercial quality of honey (as amended), [9] 'honey' is a naturally sweet substance produced by Apis mellifera bees from the nectar of plants or secretions of living parts of plants or excretions of insects sucking the juices of living parts of plants, collected by bees, processed by combining specific substances from bees, folded, dehydrated, collected and left in honeycombs for ripening. A distinction is made between two types of honey according to their origin:

a) Floral or Nectar Nectar- Obtained from vegetable nectar

b) And Honeydew - Obtained mainly from excretions of insects sucking (Hemiptera) the living parts of plants or secretions of living parts of plants.

c) However, depending on the method of obtaining or packing, a distinction is made: Sectional, collected by bees in the cells of a freshly built broodless comb or freshly built comb made exclusively from beeswax and sold in sealed comb or parts of sealed comb,

d) With Plasters - containing one or more pieces of plasters,

e) Drained - Obtained by draining uncovered broodless combs,

f) Centrifuged - Obtained by centrifuging uncovered broodless combs,

g) Extruded - Obtained by pressing broodless combs with or without the application of moderate heat not exceeding $45^{\circ} \mathrm{C}$ and 
h) Filtered - Obtained by removing foreign inorganic or organic matter, including the removal of a significant amount of pollen.

The nectar honey variety is determined on the basis of the proportion of primary pollen in the honey. The name of the honey derives from the name of a plant whose pollen in the honey is predominantly pollen. It is assumed that the proportion of lead pollen in buckwheat, heather and rapeseed honeys must not be less than $45 \%$. In the case of acacia, the minimum content of robinia pollen is $30 \%$ and lime pollen in lime honey may not be less than $20 \%$. These are the so-called undistrushed honeys, which come from plants with a low pollen yield of a given plant PuszczcionJakubik A [10] The quality of honey is determined by its colour, taste, consistency and aroma. The specific gravity, optical rotation, viscosity, acidity and electrical conductivity are also important parameters of honey Marciniak E [3]. The specific gravity of honey is the ratio of its mass to its volume and should be within the range of $1380-1450 \mathrm{~g}$.

Too low a weight may result from too high a content of water. Optical rotation is affected by the content of dextrins and differs depending on the type of honey. Nectar honeys are characterized by a negative value of this parameter (e.g. acacia- $17^{\circ}$ ), while honeydew honeys $+4.2^{\circ}$ Marcinak E [3]. The viscosity of honey is another physicochemical parameter taken into account. The viscosity depends on the temperature and water content. Honeydew honeys show higher viscosity than nectar honeys. The higher the water content of honey at the same temperature, the lower the viscosity value $P$ (puaza). The acidity of honey is characterised by two parameters: reaction and total acidity. The $\mathrm{pH}$ of the honey ranges from 3,95 (nectar honeys) to 4,2 (honeydew honeys). The total acidity of the honey is determined by free acids and lactose and varies according to its variety (spring, full summer, autumn). The total acidity ranges on average from $21,2 \mathrm{mval} / \mathrm{kg}$ (spring honeys) to $36,2 \mathrm{mval} / \mathrm{kg}$ (autumn honeys) to about $42,0 \mathrm{mval} / \mathrm{kg}$ (summer honeys). The electrical conductivity also varies depending on the variety of honey and the origin of the honey. Electrical carriers are ions contained in honey, while conductivity reduces proteins and carbohydrates Majewska E. et al. [7]. It is caused by their large size which makes it difficult for them to move and additionally slows down the movements of ions. The highest electrical conductivity is observed in autumn honey $\left(787 \mu \mathrm{S} \mathrm{cm}^{-1}\right)$, the lowest in spring $(259 \mu \mathrm{S}$ $\mathrm{cm}^{-1}$ ) and in spring Marciniak E [3]. Each of the honeys should meet organoleptic as well as physicochemical requirements. The regulation specifies the requirements as to colour, consistency, taste and smell. The criteria for the following parameters and methods of analysis were defined: water content, fructose and glucose content, sucrose content, water insoluble substances content, conductivity, free acids, diastase and 5-hydroxymethylfurfural content.

Each honey must meet certain qualitative and quantitative criteria. This may result in a special designation as regional and traditional products of the highest quality. These are products that have been awarded a European label or an application for a European label has been sent by the Ministry of Agriculture and Rural Development to Brussels. European designations include: Protected Designation of Origin, Protected Geographical Indication and Traditional Specialist Guaranteed. Quality and authenticity are also guaranteed by the 'Quality Tradition' scheme. It is a national food quality system notified to the European Commission and created and managed by the Polish Chamber of Regional and Local Products and the Union of Voivodships of the Republic of Poland. The awarding of marks confirming the high quality of products is one of the ways of implementing the quality policy in the EU and results from the implementation of the second pillar of the Common Agricultural Policy. Among the products bearing the European designation Protected Designation of Origin are two honeys: Podkarpacki miód spadziowy and Miód z Sejneńszczyzny/ Miód z Łoździej.

Products bearing the Protected Geographical Indication designation include three types of honey: heather honey from Bory Dolnośląskie-Dolny Śląsk, drahimski honey and kurpiowski honey - Kurpie. However, only one honey has the Quality and Tradition label Lime Honey from the French Breed. (http://www.minrol.gov. $\mathrm{pl}$ ). As of today, 65 types of honey have been included in the list of traditional products in Poland. The division into provinces is as follows (source: minrol.gov.pl):

a) Dolnośląskie 6: Sudecki multiflorous honey, Sudecki buckwheat façade, Large-flowered honey from the Barycz Valley, Heather honey from the Lower Silesian Forests, Lime honey krupiec from Ząbkowice Land, Ryczyński lime honey;

b) Kuyavian-Pomeranian Voivodship 1: Honey from the Lower Vistula area; lubelskie voivodship 8: Nadwyprzański linden honey, rape honey from Roztocze, buckwheat honey from Lubelszczyzna, buckwheat honey, raspberry honey, varietal bean honey with nectar flowers, bean stakowych "Piękny Jaś", Nałęczów multi-flower honey;

c) Voivodship 3 in Łódź: Honey from the Mroga River valley, honey from the Żelechlinek commune, honey from Brzesinska Land, Wyżnień Łódzki and Rawki;

d) Lubuskie Voivodship 5: Honey meadow grandiflorum from the Notci Valley, Acacia honey, herbaceous Nettle, Magnesian Lime honey, Nectar-honeysuckle honey;

e) Małopolskie Voivodship 6: Sądecki miód spadziowy, Małopolski miód spadziowy, Suski Honeydew honey from coniferous trees, Multiflower forest honey from Podksięża, Goldenrod Honey from Skrzyszów Commune, honey from fir honeydew from Pogórze Rożnowskiego; mazowieckie voivodship 7: Nadbużański honey, Miód kurpiowski, Honey from Grębków, Marian honey, Multiflower meadow honey from Kornica, Multiflower honey from Ziemia Tłuszczańska, Perła Urzecza - goldenrod honey; 
f) Opolskie Voivodship 3: Popielówskie Honey from Bory Stobrawskie, Rudnik honey, Honey of Wales;

g) Podkarpackie Voivodship 3: Honey from Korzenica, multiflorous and nectar-spadziowy, Miód lubaczowski, podkarpacki miód spadziowy;

h) Podlaskie Voivodship 3: honey polygon from Sejnyńszczyzna, Lipiec białowieski, Miód augustowski; Pomeranian Voivodeship 3: Forest honey from Biernatki, Pszczółkowski Honey, Kashubian Honey;

i) Śląskie Voivodship 4: Lime-hairy honey of the Cieszyn Land, rapeseed Honey of the Cieszyn Land, Honey from the nectar of Jurassic flowers, Honey from Żywiec Land;

j) Świętokrzyskie Voivodship 6: Świętokrzyski honeydew honey, Fałkowski multi-flower honey, Royal honey from Osiek, Honey nectar-spadziowy napękowski, Honeydew honey from the fir forest, Acacia honey from Łążek;

k) Warmian-Masurian Voivodship 4: Honey Mazur Garbate, Linden honey from Barcja, Multiflower honey from Barcja, honey from the Olecko region;

l) Wielkopolskie Voivodship 2: Honey wito Sławski, Honey from Kopaszew;

m) West Pomeranian Voivodship 9: Honey Drahimski, Miody przelewickie, Honey wales, Action honey honey cedyński, Honey from the Holy Mary's Forest, Honey Forest Barliniecka, Miody Pojezierze Choszczeńskiego, Honey Dębicki, Honey Rusynowskie.

Unfortunately, the methods of honey falsification are developing faster and faster, they are more and more complicated and sophisticated. It is mainly based on adding sucrose, molasses, potato syrup, sugar or corn syrup to the honey. These syrups are difficult to detect because the sugar profile is very similar to natural honey. Quite often forgery consists in mixing different varieties of honey and then incorrect labelling of the product. Added substances are difficult, even impossible to detect organoleptically, which is why newer and newer methods of detection are being developed. Luczyńska D et al. [6]. Examples of methods for detecting honey adulteration may include Lane-Einon and Luff-Schoorl methods for the detection of sucrose adulteration in honey, SCIRA-MS method for the detection of cane and maize adulteration in honey and HPAEC-PAD method for the detection of beet sugar. The truthfulness of botanical origin is confirmed by the HPLC-DAD method. For the detection of maltodextrins formed in starch syrups the latest method is the HPLC method. Electric permeability may also be used to detect forgery in honey. It can also be used to distinguish between natural and artificial honeys Hodujko M (2016) [11-14].

\section{References}

1. Basista $K$ (2013) Biological and health properties of honey and its use as health food. In Gazeta Farmaceutyczna p. 26-28.

2. Ball D (2007) The chemical composition of honey. Journal of Chemical Education 84: 1643-1646.

3. Marcinak E (2014) Calendar of the Polish Beekeeper.

4. Hodujko M (2016) Adulteration in honey and methods of its detection. In: Knowledge and quality. Quality inspection of Commercial Agro-Food Products 1(42): 33-39.

5. Śliwińska A, Bazylak G (2011) Initial assessment of bee honeys quality based on selected physicochemical and microbiological parameters. In: Bromatology and Toxic Chemistry XLIV 3: 784-791

6. Łuczyńska D, Szewczyk A, Pruski K (2011) Electrical methods for detecting honey adulterations. Inżynieria Rolnicza 5: 130.

7. Majewska E, Delmanowicz A (2009) Physicochemical properties of bee honeys as criteria for their authenticity. Inż Ap Chem 48(1): 036-037.

8. (2003) Regulation of the Minister of Agriculture and Rural Development on specific requirements in terms of commercial quality of honey.

9. (2009) Regulation of the Minister of Agriculture and Rural Development on the methods of analysis related to the assessment of honey (with later amendments).

10. Puścion Jakubik A, Borawska M (2016) Variety honeys honey - main pollen and accompanying pollen as the basis for their qualification. Probl Hig Epidemiol 97(3): 275-278.

11. (2011) Inspection of the Commercial Quality of Agricultural and Food Products. Collective information on the results of ad hoc controls on commercial honey quality dated.

12. (2009) Office of Competition and Consumer Protection. Consumer's report on the food market (in the light of the results of the inspection of dairy, meat, fish and honey products).

13. Polish Standard PN-88/A-77626 Honeybees.

14. Website of the Ministry of Agriculture and Rural Development.
ISSN: 2574-1241

DOI: 10.26717/BJSTR.2019.19.003374

Katarzyna Szyszko-Podgórska. Biomed J Sci \& Tech Res

This work is licensed under Creative Commons Attribution 4.0 License

Submission Link: https://biomedres.us/submit-manuscript.php

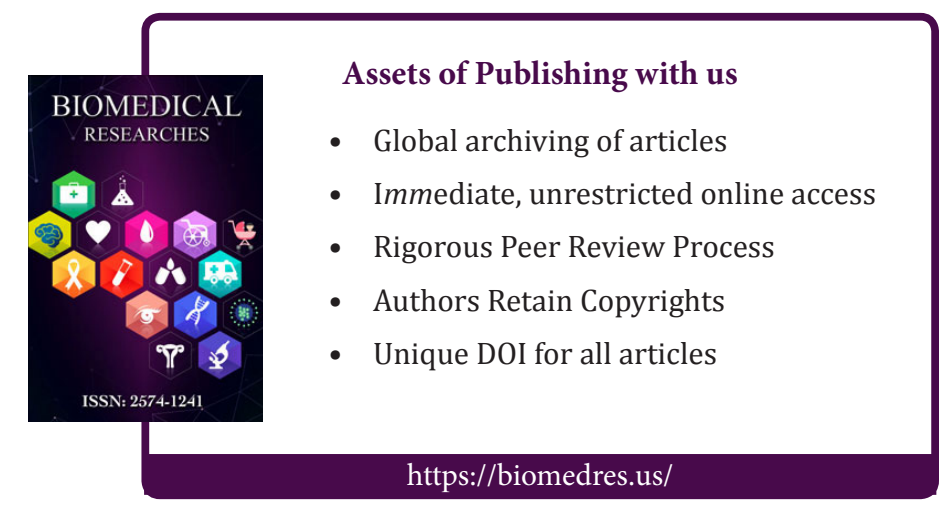

